\title{
Sistem Informasi Geografis Peternakan AyamPada Kabupaten Jembrana Berbasis Website
}

\author{
Ni Made Mila Fatmasari ${ }^{1}$, I Putu Agus Swastika ${ }^{2}$, Nengah Widya Utami ${ }^{3}$ \\ Program Studi Sistem Informasi \\ Sekolah Tinggi Manajemne Informatika dan Komputer \\ Denpasar, Bali, Indonesia \\ E-mail : $\underline{\text { milafatmasari09@gmail.com }}{ }^{1}, \underline{\text { masagusswastika@gmail.com }}^{2}$, widya@ primakara.ac.id ${ }^{3}$
}

\begin{abstract}
This thesis proposal discusses the difficulties of chicken buyers to get information on chicken farms in Jembrana Bali, and the limited information obtained, currently complete information on farm layout in Jembrana Regency, only exists at the Jembrana District Animal Husbandry Service, then chicken breeders are also it is still difficult to provide information about their layout due to the limited means of adequate information in each village. So a chicken farm geographic information system was created with the aim of helping chicken buyers, livestock raisers and the Chicken Farming Service to get information on chicken breeding in Jembrana Regency more easily.
\end{abstract}

Keywords-livestock, chicken, GIS, Website, Jembrana

\section{PENDAHULUAN}

Jembrana adalah sebuah kabupaten di Bali yang berada di bagian barat pulau Bali, Kabupaten Jembrana memiliki banyak objek wisata, pertanian serta petenakan, dari segala keindahan yang ada pada Kabupaten Jembrana Bali terdapat juga banyaknya pertanian hingga peternakan disetiap desanya, perternakan-petenarkan tersebut sudah ada sejak lama di Kabupaten tersebut, namun sayangnya tidak terlalu banyak diketahui oleh orang-orang disekitar wilayah tersebut [1].

Potensi perternakan pada Kabupaten Jembrana Bali, Jembrana merupakan daerah produktif menjadi kawasan peternakan, berkisar $32.421 \mathrm{~km} 2$ atau sekitar 38,51\% dari luas Wilayah Kabupaten Jembrana, yang terdiri dari daerah persawahan, perkebunan, dan lain sebagainya. Sistem Informasi Geografis adalah suatu informasi mengenai tataletak suatu wilayah atau objek tertentu dan memberikan berbagai informasi terkait tataletak dari wilayah maupun objek tersebut [2], sistem informasi geografis dalam hal ini berguna untuk memberikan informasi tataletak dari setiap peternakan yang ada pada Kabupaten Jembrana Bali.

Dari wawancara yang dilakukan di dinas peternakan Kabupaten jembrana, dengan Bapak Kastama selaku Kabid Peternakan, didapatkan hasil bahwa penting jika adanya sebuah pemetaan untuk lokasi setiap peternakan ayam yang dapat membantu memudahkan para pembeli dalam menemukan tataletak setiap peternakan terdekat diwilayah mereka masing-masing, serta diharapakan juga dapat membantu dinas dalam memberikan informasi kepada para pembeli mengenai tataletak peternakan yang ada diwilayah Kabupaten Jembrana, selain itu juga membantu pihak dinas dalam menerima informasi pemetaan peternakan ayam pada Kabupaten Jembrana.

Dari wawancara yang dilakukan pada peternak ayam, mereka membenarkan bahwa banyak orang yang belum mengetahui keberadaan mereka disana, kurangnnya sosialisasi dan keterbatasan pengetahuan tentang cara mempromosikan menjadi masalah hampir pada semua peternak ayam diwilayah Kabupaten Jembrana.

Dari wawancara yang dilakukan pada pedagang, dan supplier ayam yang biasa membeli dan menerima pengiriman ayam dari pemasok ayam yaitu peternak ayam diwilayah sekitar Kabupaten Jembrana maka penulis mendapatkan informasi lain diantaranya adalah kesulitan untuk mendapatkan informasi dan tataletak perternak ayam disekitar wilayah tersebut, biasanya mereka hanya bergantung dan mengandalkan pada satu pemasok ayam, dan tidak memiliki pilihan lain untuk membeli ayam dalam jumlah besar sehingga sering kali hanya bergantung pada satu pemasok dari satu petenakan ayam saja. Dari permasalahan tersebut maka penulis membuat ide tentang sebuah pemetaan yang bertujuan agar para pedagang dan supplier ayam mengetahui dimana saja peternak-peternak ayam diwilayah Jembrana berada dan juga agar memudahkan pembeli tersebut untuk menemukan dan mendapatkan informasi mengenai mengenai tata letak dan informasi terkait perternakan diwilayah Jembrana, maka akan dibuatkan sistem informasi geografis peternakan ayam berbasis website. 


\section{e-ISSN: 2685-7006 | p-ISSN: 2252-9063 \\ Kumpulan Artikel Mahasiswa Pendidikan Teknik Informatika \\ (KARMAPATI)}

Volume 10, Nomor 2, Tahun 2021

KคRMดPดTI

Berdasarkan permasalahan dan penjelasan di atas, maka penulis mencoba untuk membuat sebuah solusi mengenai sistem informasi geografis perternakan ayam berbasis web yang diharapkan akan membantu para supplier ayamataupun pedagang pasar dan pembeli ayam potong untuk menemukan pemasok ayam (peternak ayam) yang ingin mereka kunjungi diwilayah Jembrana Bali. Maka penulis merancang tugas akhir yang berjudul "Sistem Informasi Geografis Peternakan Ayam Pada Kabupaten Jembrana Berbasis" aplikasi ini diharapkan dapat membantu para pembeli ayam untuk untuk mendapatkan informasi tata letak peternakan ayam di Kabupaten Jembrana Bali.

\section{KAJIAN TEORI}

\section{A. SIG (Sistem Informasi Geografis)}

SIG adalah sistem informasi geografis, SIG secara garis besar adalah sebuah informasi yang menampilkan suatu keadaan, tempat, keberadaan ataupun sebuah wilayah tertentu yang digambarkan dalam sebuah peta ataupun tataletak, sig membantu seseorang dalam memberikan berbagai informasi tentang lokasi, keberadaan di wilayah tertentu, maupun tempat dalam bentuk peta ataupun satelit [2].

\section{B. Perternakan}

Peternakan adalah kegiatan mengembang dan memelihara hewan ternak untuk mendapatkan suatu hasil dari aktifitas tersebut. Hewan yang diternakkan di antaranyababi, ayam, kambing, dan bebek. Hasil peternakan ada banyak dari daging, hingga telur, dan bahan pakaian (sepertitas kulit). Selain itu, kotoran hewan dapat menyuburkan tanah subur dan tenaga hewan dapat digunakan sebagai sarana perjalanan dan untuk membajak sawah [3].

\section{Perternakan Ayam}

Peternakan ayam adalah ladang atau perkembangbiakan ayam pada suatu tempat, yang terus berulang dan berkembang biak serta dapat diperjual belikan untuk menjadi rantai pasok perputaran perkembangan ayam disuatu perternakan tersebut, contoh lainnya ayam di kembangbiakan sampai menjadi banyak dan dikurangi jumlahnya dengan diperjual belikan, maka rantai pasok dapat berputar secara berulang sehingga menghasilkan pola ternak yang seimbang dan berjalan terus menerus [3].

\section{Sistem Informasi}

Sistem informasi merupakan suatu data yang memberikan informasi untuk mengelola data dalam mengambil persetujuan dan juga untuk melakukan kinerja yang akurat, di mana sistem tersebut merupakan kombinasi dari orang-orang, teknologi informasi dan proses yang terorganisasi. suatu perusahan selalu menyediakan sumber informasi yang berguna bagi perusahaan itu sendiri. Sebagai contoh: Perusahaan toko majalah meberikan informasi terkai majalah yang akan dipasarkan ataupun diperjual belikan [4].

\section{E. API Google}

API google merupakan sumber informasi dari google API Maps yang memberikan akurasi, ketepatan dan juga ifisiensi untuk suatu wilayah yang akan menjadi target kunjungan seseorang baik melalui lokasi maupun melalui wilayah [2].

Api Google digunakan untuk menghubungkan antara google, maps, dan sistem yang akan dikembangkan, tujuannya untuk mendapatkan kode yang aktif untuk digunakan sebagai pengaktifan maps sehingga maps dapat digunakan disistem yang akan dibangun, dikembangkan maupun dirancang [2].

\section{F. HTML}

Html merupakan sebuah Bahasa pemograman script berupa artikel-artikel Bahasa, html digunakan sebagaiBahasa dasar dalam pembuatan sistem, html digunakan untuk membuat sebuah form dan alir dari aplikasi itu sendiri, html terus dikembangkan dan html banyak digunakan sebagai latihan dasar pengacuan dan pembelajaran sebelum memulai pemograman yang lebih luas dengan cakupan yang lebih besar html dimulai dari beberapa sintax dasar yaitu kepala, body dan bawah, dimana kepala sebagai judul, body sebagai badan dan bawah sebagai dasar dari bagian bawah suatu tampilan yangakan dibuat melalui Bahasa HTML nantinya

\section{G. $P H P$}

PHP adalah Bahasa pemograman yang lebih luas dari Html, php digunakan untuk membuat program yang lebih kompleks, PHP sangat bagus untuk membuat program dengan kelas yang cakupannya lebih besar, PHP juga bermanfaat untuk perkembangan website [5]

PHP dapat membuat banyak aplikasi seperti web, apps, wordpress, jomla dan banyak jenis lainnya, PHP terus berkembang dan menjadi andalan untuk semua pengguna yang ingin membuat web untuk perusahaan dan bisnis pribadi mereka, PHP juga sudah terkenal sejak lama hingga saat ini [5].

\section{H. Mysql}

Mysql digunakan sebagai database suatu sistem, mysql dipercaya membantu dalam penyimpanan data secara structural, mysql berkembang dengan baik dan menjadi andalan untuk user dalam membuat sistem, mysql digunakaan sebagai pilihan utama database yang digunakan, database merupakan penyimpanan data sebuah sistem 


\section{e-ISSN: 2685-7006 | p-ISSN: 2252-9063 \\ Kumpulan Artikel Mahasiswa Pendidikan Teknik Informatika \\ (KARMAPATI)}

Volume 10, Nomor 2, Tahun 2021

KคRMดPดTI

aplikasi yang dibuat, Mysql merupakan database untuk sistem tersebut [5]. Mysql terkoneksi dengan sistem melalui sebuah Bahasa koneksi PHP dan beberapa sintax HTML, Mysql membantu menyimpan dan menampung berbagai data untuk sebuah sistem, Mysql juga dapat menampung banyak data dan segala jenis data dengan struktur yang sama dan perintah yang sesuai untuk menjalankan dan menyambungkan sebuah web dengan database Mysql tersebut [5].

\section{ERD (Entity Relationship Diagram)}

ERD merupakan sebuah kumpulan flow yang menggambarkan database yang ingin dirancang kedepan sehingga memiliki struktur yang jelas sebelum dimasukan kesebuah Bahasa pemograman [2].

\section{METODE PENELITIAN}

Dalam menentukan metode penelitian yang digunakan penulis dalam penelitian ini adalah metode prototipe, metode prototipe adalah Sebuah prototipe bagian dari produk yang mengekspresikan tampilan maupun ilustrasi antarmuka luar yang ditampilkan. Konsumen akan menggunakan prototipe dan menyediakan masukan untuk tim pengembang sebelum pengembangan skala tinggi dimulai. Prototipe dapat dibentuk dalam rancangan seperti flowchart ataupun DFD, dan ERD, bisa juga dalam bentuk gambaran umum sistem yang akan dibuat nantinya. Melihat dan mempercayai menjadi hal yang diharapkan untuk dicapai dalam prototipe. Dengan menggunakan pendekatan ini, konsumen dan tim pengembang dapat mengklarifikasi kebutuhan dan interpretasi mereka [6].

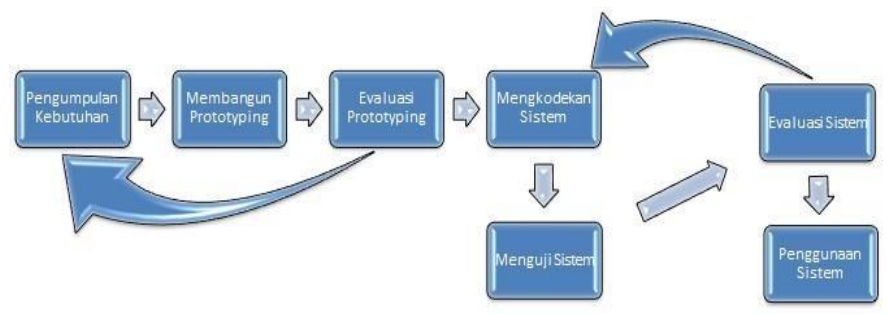

Proses-proses dalam metode Prototyping penulis jabarkan sebagai berikut:

1. Pengumpulan kebutuhan

Bersama-sama mendefinisikan format aplikasi, mengidentifikasikan semua kebutuhan, dan garis besar sistem yang akan dibuat. Dalam tahap ini peneliti mengumpulkan informasi yang dibutuhkan pembeli ayam dan peternak ayam melaluiobservasi wawancara pada pembeli, perternakhingga Dinas Peternakan dan juga studi literatur.

2. Membangun prototyping
Membangun prototyping dengan membuat perancangan sementara yang berfokus pada penyajian kepada pelanggan. Dalam tahap ini penelitian menggambarkan prototype secara umum melalui DFD Diagram Konteks hingga ERD dan juga ilustrasi gambaran umum interaksi yang akan terjadi pada sistem dalam bentuk gambaran prototipe untuk solusi sistem yang akan dirancang dan gambaran umum untuk dievaluasi.

3. Evaluasi protoptyping

Evaluasi ini dilakukan oleh pelanggan apakah prototyping yang sudah dibangun sudah sesuai dengan keinginann pengguna. Jika sudah sesuai maka langkah akan diambil. Jika tidak prototyping direvisi penulis akan mengulang langkah 1,2, dan 3. Dalam hal ini penulis menunjukan gambaran umum DFD diagram konteks yang dibuat dan gambaran umum siklus interaksi pada sistem yang akan dibuat guna untuk menjelaskannya kepadauser pembeli serta peternakan dan juga Dinas Peternakan, agar mengevaluasi gambaran umum prototipe sistem yang akan dibuat nantinya.

4. Mengkodekan sistem

Dalam tahap ini prototyping yang sudah di sepakati diterjemahkan ke dalam bahasa pemrograman yang sesuai misalnya php dan sejenisnya. Setelah rancangan sesuai dengan apa yang diharapkan user maka peneliti akan memulai merancang sistem dengan menggunakan Bahasa pemograman PHP dan Mysql sebagai databasenya.

5. Menguji sistem

Setelah sistem sudah menjadi suatu perangkat lunak yang siap pakai, harus dites dahulu sebelum digunakan. Pengujian ini dilakukan dengan Black Box Testing. Dalam tahap ini peneliti melakukan pengujian sistem untuk mengetahui bahwa sistem sudah berjalan sesuai dengan apa yang diharapkan.

6. Evaluasi Sistem

User mengevaluasi apakah sistem yang sudah jadi sudah sesuai dengan yang diharapkan dengan Usability Testing. Jika ya, langkah berikutnya adalah lanjut ke langkah selanjutnya namun jika tidak, peneliti akan mengulangi langkah 4 dan 5 . Dalam tahap ini peneliti kembali melakukan evaluasi namun dalam tahap ini yang dievaluasi adalah program yang sudah jadi, jika sebelumnya hanya mengevaluasi gambaran sistem yang akan dibuat, dalam tahap ini peneliti melakukan evaluasi tentang program yang sudah dibuat, dievaluasi untuk melihat hasil apakah sistem yang 


\section{KคRMดPคTI}

dibuat sudah sesuai dengan yang diharapkan oleh user.

7. Menggunakan sistem

Perangkat lunak yang telah diuji dan diterima user siap untuk digunakan. Jika aplikasi sudah berjalan sesuai dengan apa yang diharapkan oleh user pembeli, perternakan ayam serta dinas perternakan maka dapat disimpulkkan bahwa sistem sudah sesuai dengan apa yang diharapkan dan siap untuk digunakan oleh para user kedepannya.

Sumber data dalam penelitian ini diperoleh dari hasil wawancara yang dilakukan penulis dengan pemilik perternakan, pembeli ayam, dan juga Dinas Perternakan Kabupaten Jembrana. Jenis data yang digunakan dalam penelitian ini adalah data kualitatif yaitu sumber jenis data yang berupa deskripsi atau teks dari hasil melakukan analisis sebuah permasalahan maupun sebuah data.

Tempat penelitian ini penulis lakukan di Kabupaten Jembrana di 4 Desa yaitu desa Sangkaragung, desa Batuagung, desa Mendoyo, dan desa Melaya. Penelitian ini dilakukan mulai dari Oktober hingga Maret 2021.

Alur penelitian dalam pembuatan penelitian ini menjelaskan mengenai tahapan danprosedur penelitian pada sistem dan alur perancangan yang akan dibuat :

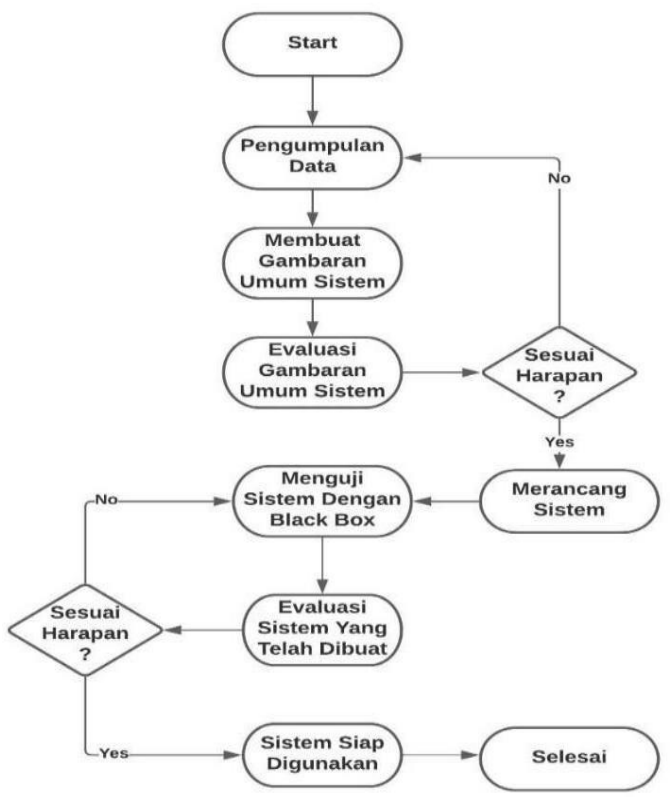

IV. HASIL DAN PEMBAHASAN

\section{A. Perancangan Usulan Sistem}

\section{Entity Relationship Diagram}

Berikut ini adalah rancangan ERD (Entity relationship diagram) untuk sistem yang diusulkan :

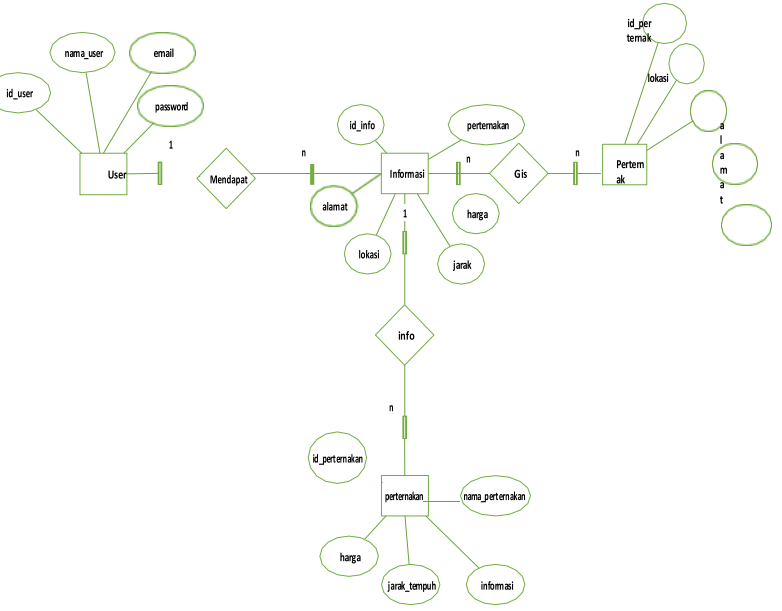

Gambar 1. ERD Sistem yang diusulkan.

\section{Implementasi}

Pada bagian ini penulis akan menampilkan hasil implementasi dari sistem yang dibangun. Berikut adalahhasil dari implementasi sistem :

\section{Halaman Home}

Halaman home adalah halaman awal untuk akses user masuk ke dalam sistem SIG peternakan Kabupaten Jembrana.

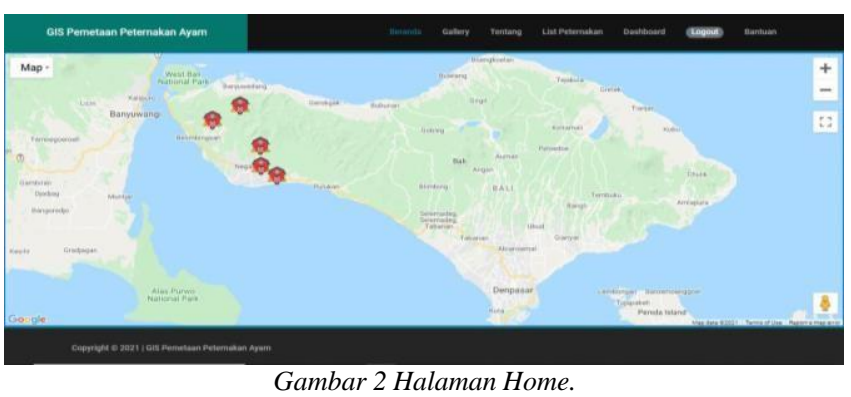

\section{Halaman Tataletak}

Halaman tata letak adalah halaman utama yang menujukan tata letak lokasi setiap peternakan yang terdapat atau terdata pada sistem sig peternakan Kabupaten Jembrana, dari sana user dapat melihat detail lokasi, detail informasi sampai dengan detail jarak untuk mengujungi dan mendapatkan informasi setiap peternak yang ada.

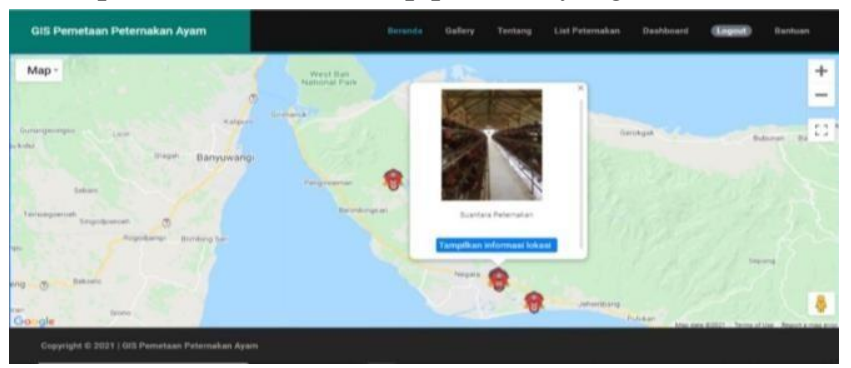

Gambar 3 Lokasi Perternak. 


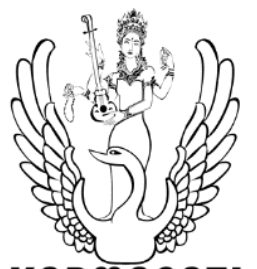

KคRMดPคTI

\section{Lokasi User}

Icon biru tersebut merupakan icon posisi user atau pengakses web berada saat ini, dan yang merah adalah lokasi perternak-pertenak yang akan dikunjungi nantinya, saat klik perternak yang dituju maka akan muncul rute perjalanan yang akan user pengguna tempuh untuk menuju lokasi tersebut dari titik lokasi pengguna itu mengakses sistem SIG.

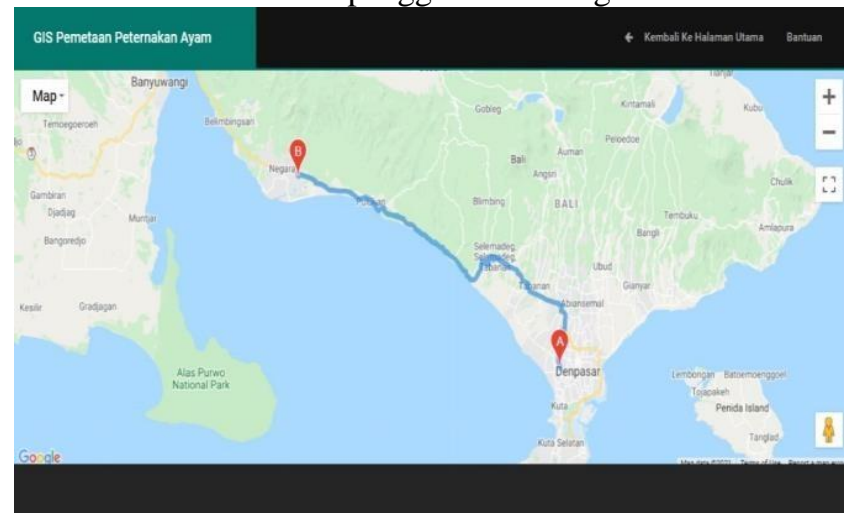

Gambar 4 Lokasi User.

\section{Menu Gallery}

Menu gallery berisikan informasi mengenai gallery sistem GIS Perternakan Kabupaten Jembrana, dibuat untuk membantu pengguna memahami tujuan dan informasisistem.

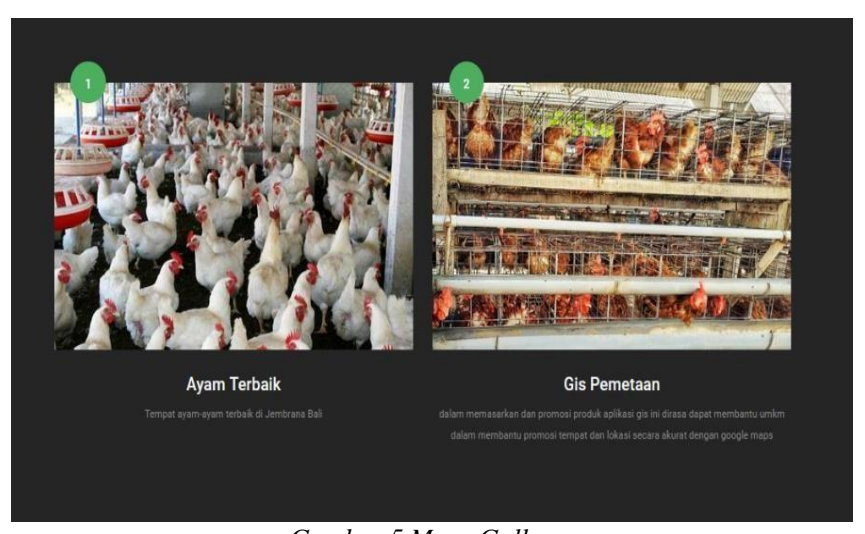

Gambar 5 Menu Gallery.

\section{Menu Tentang}

Halaman tentang memberikan informasi tentang sistem GIS Kabupaten Jembrana, dengan tujuan memberikan informasi bagi para pengguna untuk mengetauidetail sistem.

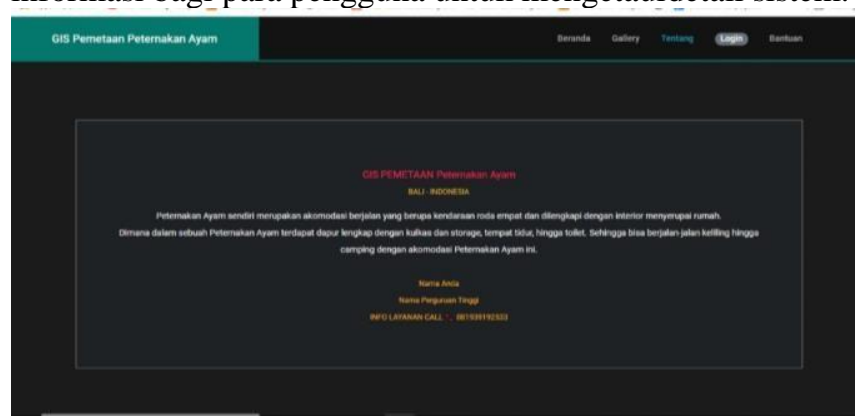

Gambar 6 Menu Tentang.
e-ISSN: 2685-7006 | p-ISSN: 2252-9063

Kumpulan Artikel Mahasiswa Pendidikan Teknik Informatika

(KARMAPATI)

Volume 10, Nomor 2, Tahun 2021

\section{Menu Bantuan}

Menu bantuan berisikan informasi untuk para pengguna yang mengalami permasalahan terkait pengaksesan sistem untuk mengirim pesan kepada admin agar diberikan solusi.

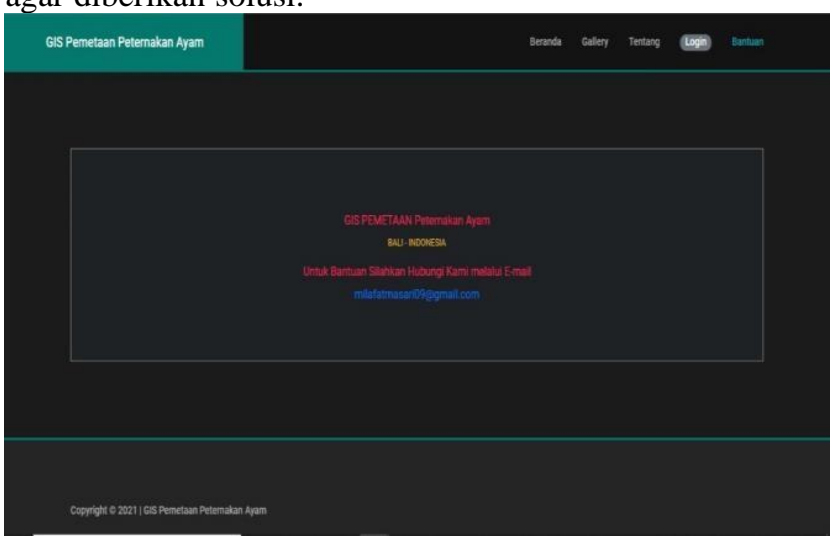

Gambar 7. Halaman Bantuan.

\section{Halaman login pengguna}

Pengguna diminta untuk login jika ingin mengakses lebih detail dan lebih rinci mengenai isi dari sistem GIS Peternak.

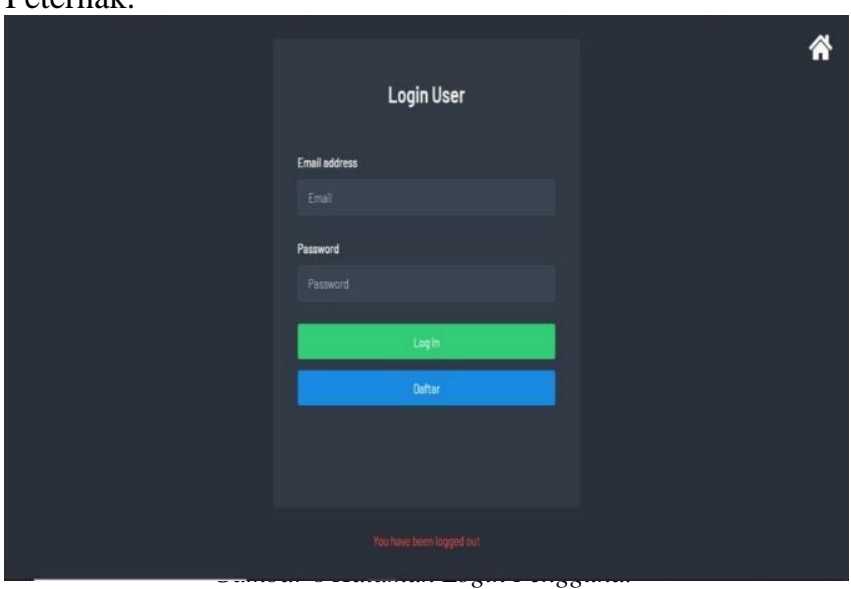

8. Halaman Daftar Pengguna

Pengguna atau user akan diminta untuk daftar atau registrasi terlebih dahulu jika belum memiliki akun.

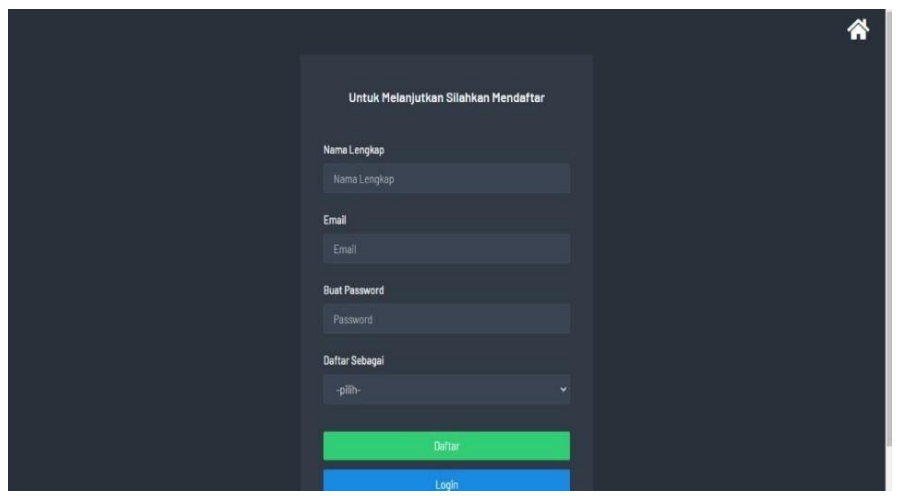

Gambar 9 Daftar Akun Pengguna. 
Kumpulan Artikel Mahasiswa Pendidikan Teknik Informatika

(KARMAPATI)

Volume 10, Nomor 2, Tahun 2021

\section{KคRMดPคTI}

9. List Detail Peternakan

Menu list peternakan menampilkan segala informasi peternak yang ada pada sistem, bisa dicari juga berdasarkan nama atau lokasi peternak itu sendiri, dapat melihat masingmasing detail informasi, detail lokasi, hinggal detail gallery.

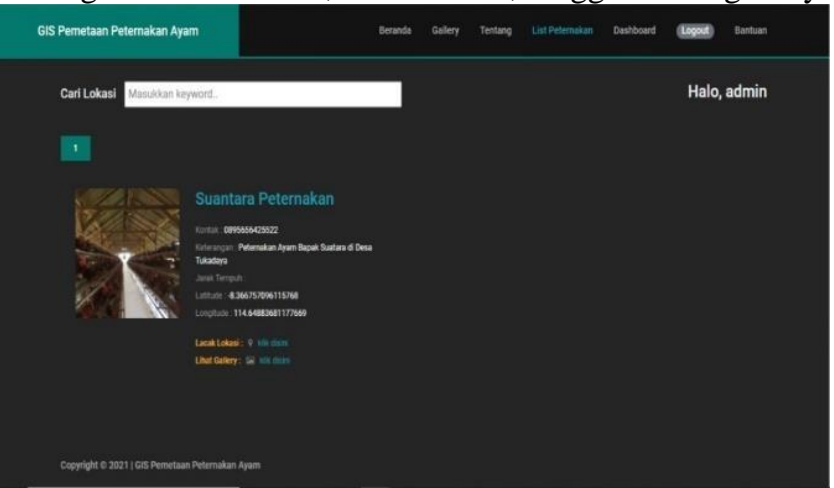

Gambar 10 List Detail Peternak

10. Menu Ubah Profil Pengguna

Menu profil pengguna, didalam sistem berfunsi untuk mengubah profil user.

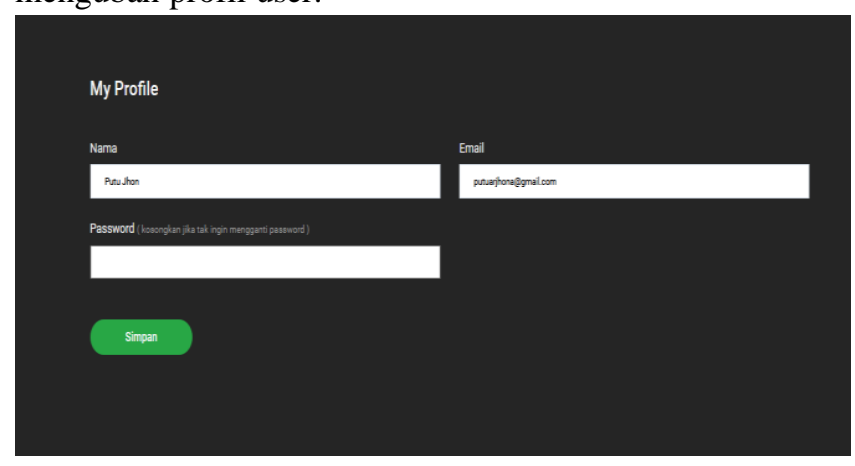

Gambar 11 Profil Pengguna User.

\section{Login Peternak}

Login peternak adalah halaman hak akses peternak untuk login masuk kedalam sistem GIS Perternak Kabupaten Jembrana, untuk mengakses lokasi dan mengatur tataletak.

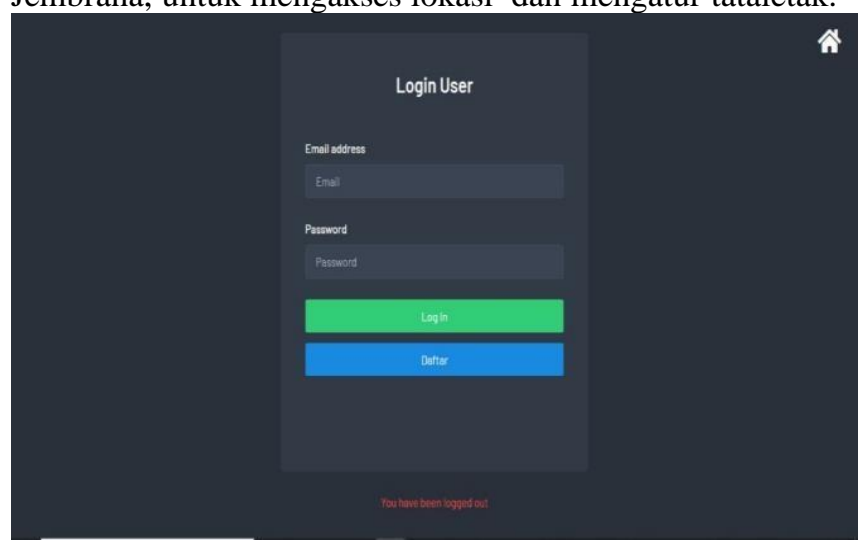

Gambar 12 Login Perternak

12. Daftar Akun Peternak

Daftar akun perternak digunakan untuk para perternak yang belum memiliki akun di sistem GIS
Peternakan, maka diminta untuk daftar terlebih dahulu dengan syarat dan ketentuan harus memiliki minimal 50 ekor ayam saat registrasi pada sistem GIS Peternakan Kabupaten Jembrana.

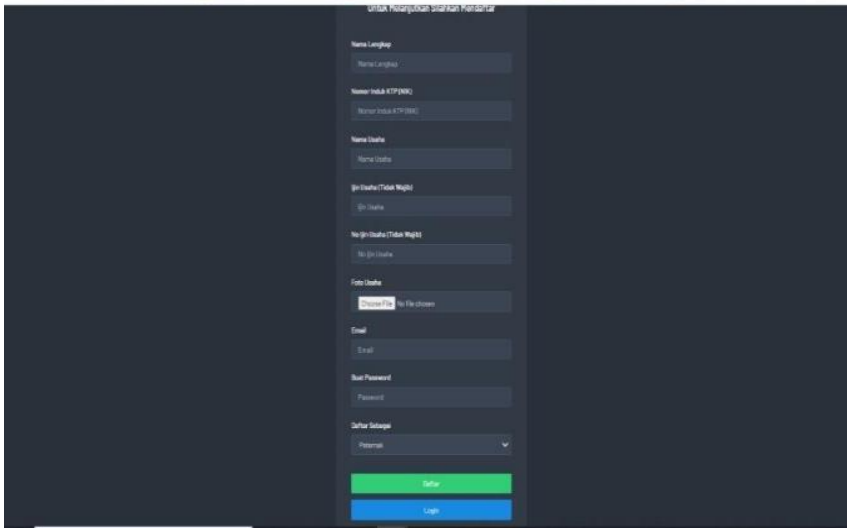

Gambar 13. Daftar Akun Peternak.

\section{Input Lokasi Peternak}

Setelah berhasil login masing-masing perternak dapat mengelelola web mereka masing-masing, dengan mengatur dan mengisi data serta membuat lokasi yang nantinya memudahkan user pengguna untuk mencari lokasi tersebut pada menu halaman awal sistem GIS Peternakan.

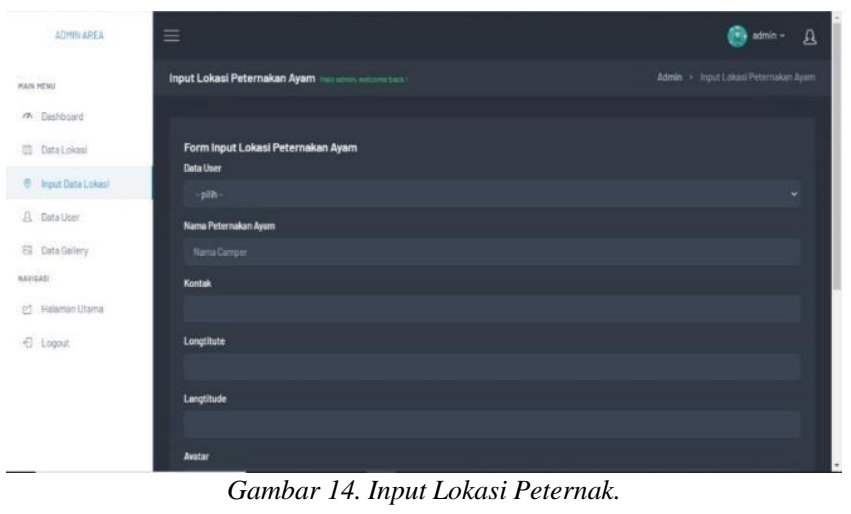

14. Ubah Profil Peternak

Data profil peternak, digunakan untuk mengubah informasi profil setiap pengguna GIS Peternak.

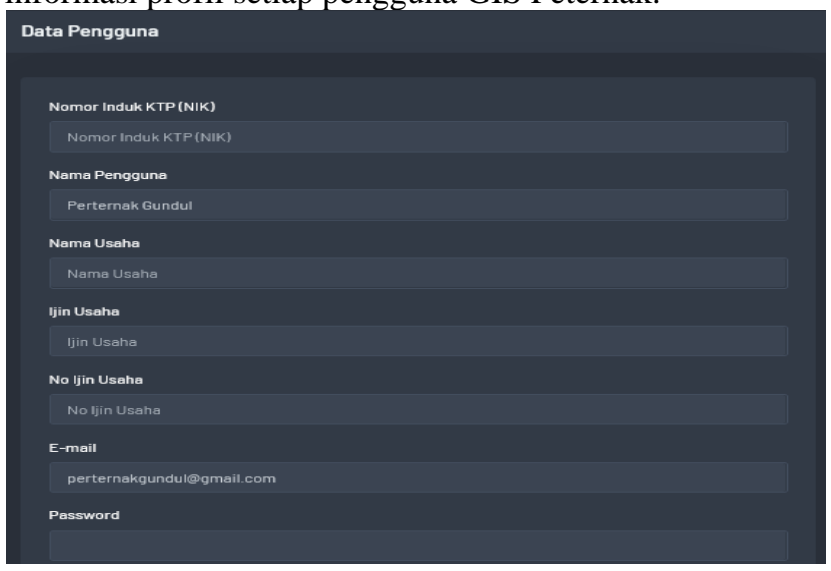

Gambar 15 Ubah Profil Peternak. 


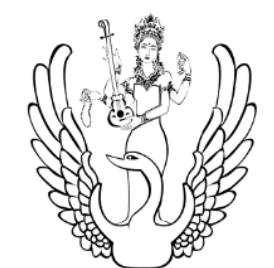

\section{KคRMดPคTI}

\section{Ubah Password Peternak}

Ubah password digunakan sebagai menu tambahan agar memperkuat password lama yang dirasa kurang kuat atau jika password sebelumnya sudah diketahui orang lain maka opsi ini bisa digunakan oleh peternak dalam memperkuat kata sandi dengan cara merubah password dengan password yang baru.

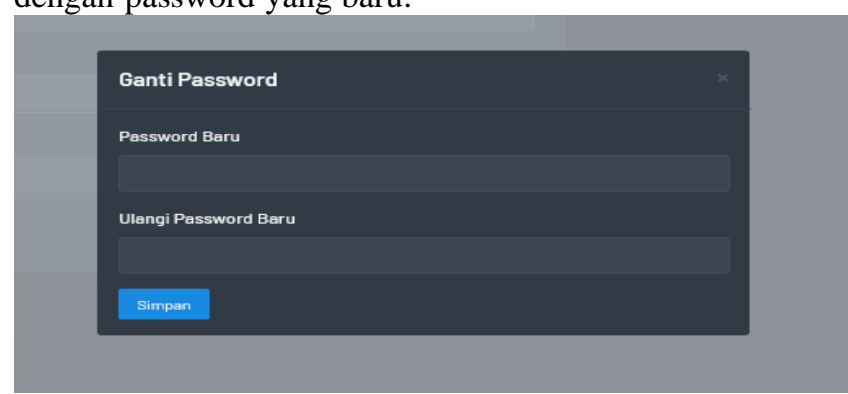

Gambar 16. Ubah Password Peternak

\section{Dashboard Peternak}

Peternak juga dapat mengakses halaman utamaseperti apa yang bisa diakses oleh user pengguna, peternak juga memiliki dan mempunyai hak akses yang sama saat masuk ke menu halaman utama, dan dapat melihat segala informasi tentang sistem web GIS Perternakan dan juga bisamelihat lokasi perternakan lainnya yang terdapat pada sistem GIS, hanya saja tidak dapat merubah lokasi pertenakan lainnya, masing-masing user perternak hanyabisa mengelola lokasi mereka masing-masing beda dengan admin yang hak aksesnya penuh sehingga bisa mengelola semuanya.

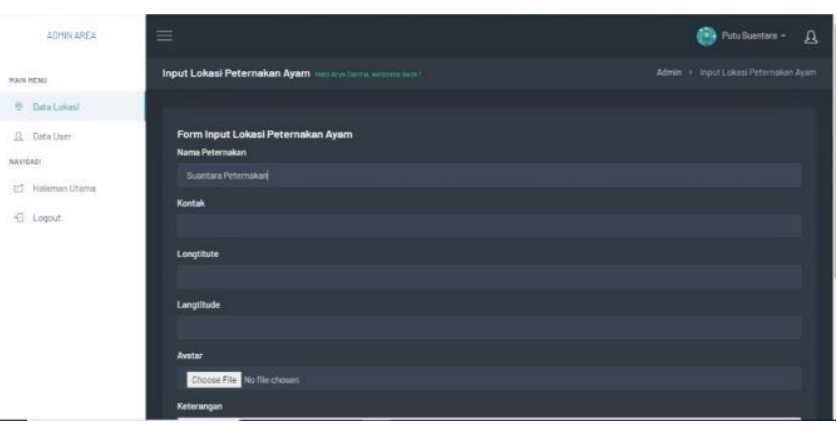

17.Logik Hak Akses Admin

Admin juga diminta untuk login agar dapat mengelola seluruh isi sistem GIS Perternakan.

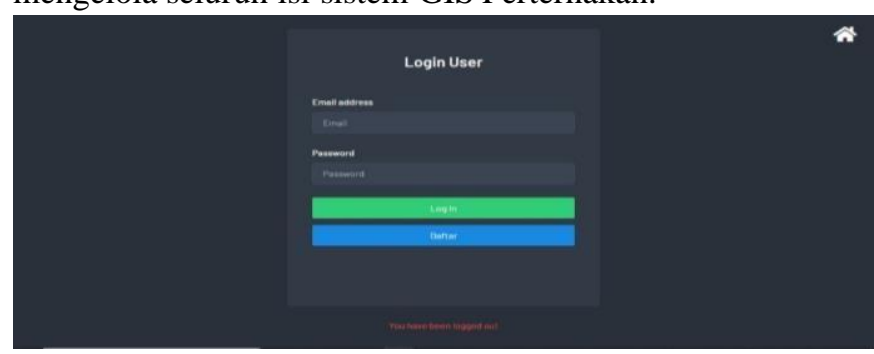

Gambar 18. Login Admin.
e-ISSN: 2685-7006 | p-ISSN: 2252-9063

Kumpulan Artikel Mahasiswa Pendidikan Teknik Informatika

(KARMAPATI)

Volume 10, Nomor 2, Tahun 2021

18. Data Lokasi Peternak

Admin dapat mengelola data lokasi seluruh perternakan yang ada pada sistem GIS Peternak.

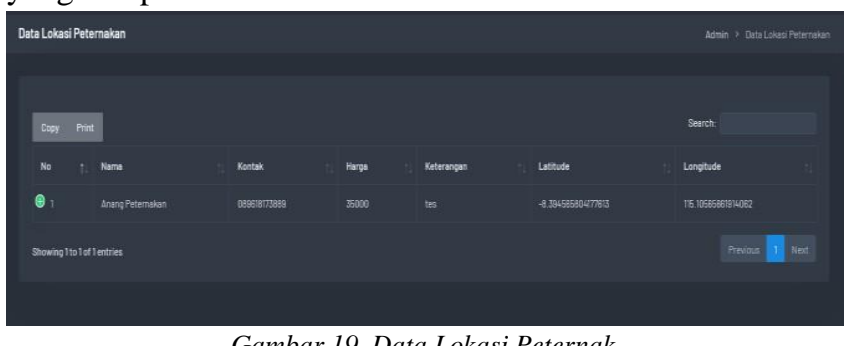

Gambar 19. Data Lokasi Peternak.

19. Cetak Data Peternak

Admin juga dapat mencetak data peternak yang ada pada sistem GIS pertenak sebagai arsip.

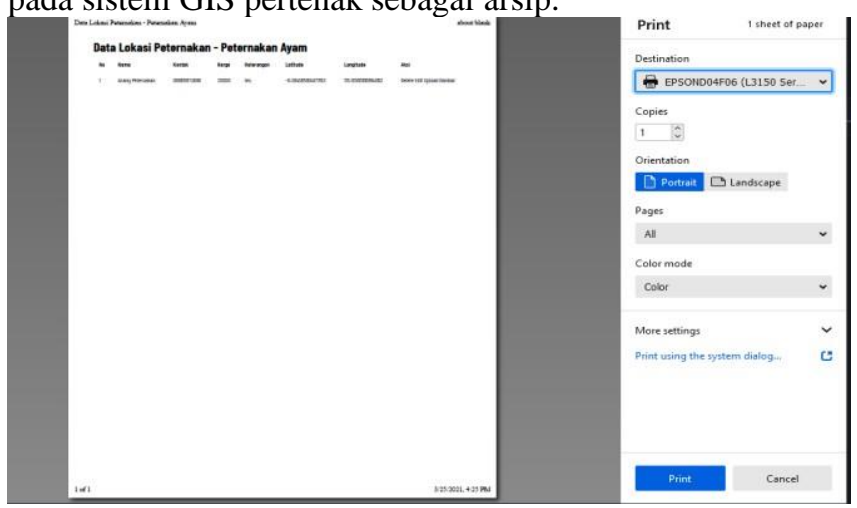

Gambar 20. Cetak Data Lokasi Peternak.

20. Dashboard Admin

Admin mempunyai dashboard pribadi, dan menumenu yang digunakan untuk mengelola sistem GIS Peternak.

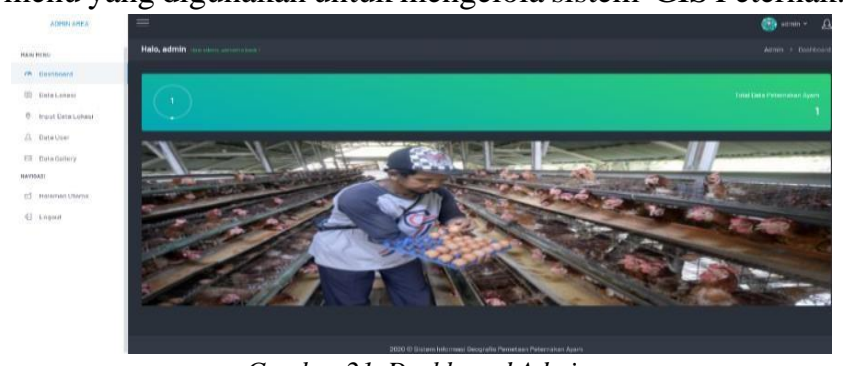

Gambar 21. Dashboard Admin.

21. Data user

Admin dapat mengelola seluruh data user yang ada pada sistem, baik menambah, mengubah, menghapus ataupun menonaktifkan user yang diagap tidak pantas atau spam.

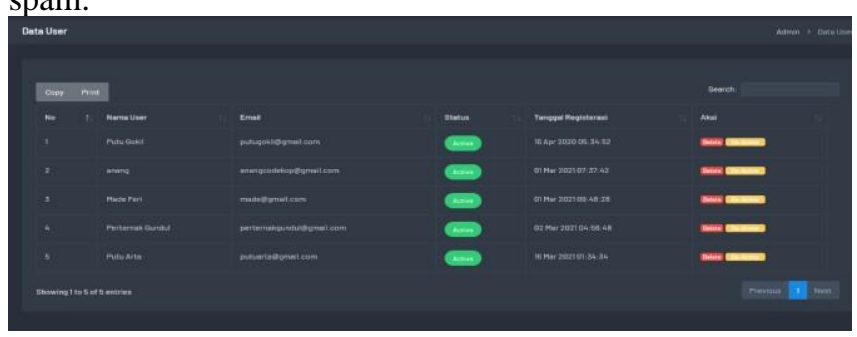




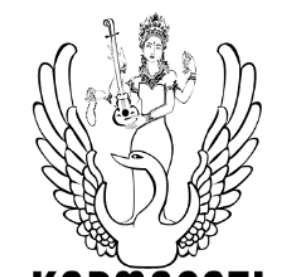

KคRMดPคTI

Gambar 22. Data User.

\section{Mengelola Dan Menambah Peternakan}

Admin juga bisa mengelola dan menambah seluruh peternakan yang diagap sesuai kedalam sistem, karena admin memiliki wewenang untuk menambah, mengubahataupun menghapus data perternak yang terdaftar didalam sistem GIS Peternakan Kabupaten Jembrana.

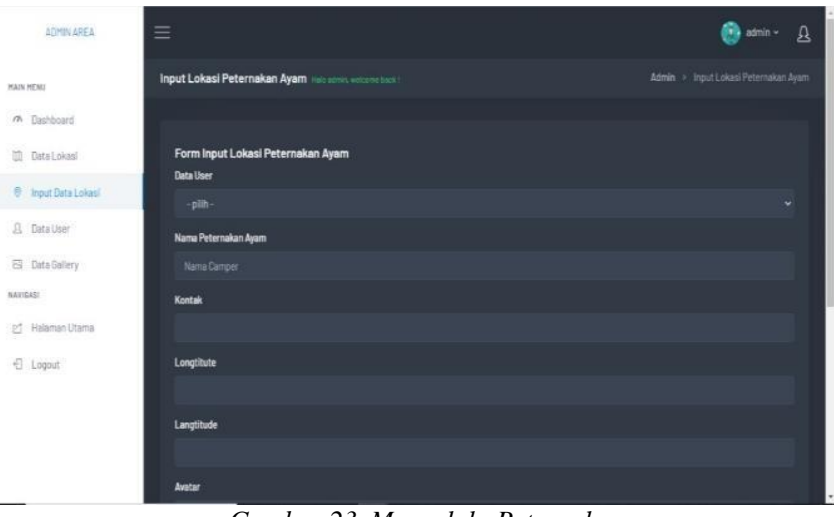

Gambar 23. Mengelola Peternak.

\section{3 .Menambah Informasi Gallery}

Admin juga dapat melakukan update-update infromasi berupa gambar dan deskripsi melalui menu gallery.

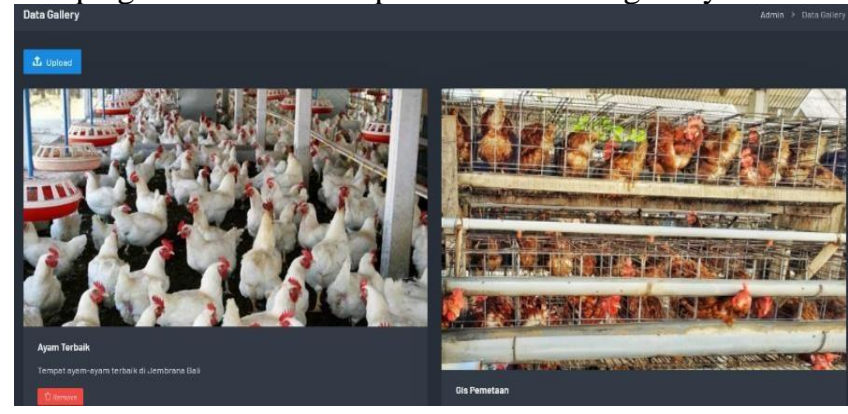

Gambar 24. Data Gallery Admin.

\section{Mengubah Password Admin}

Admin juga dapat mengubah password baru sama hal nya dengan user pengguna dan user peternak.

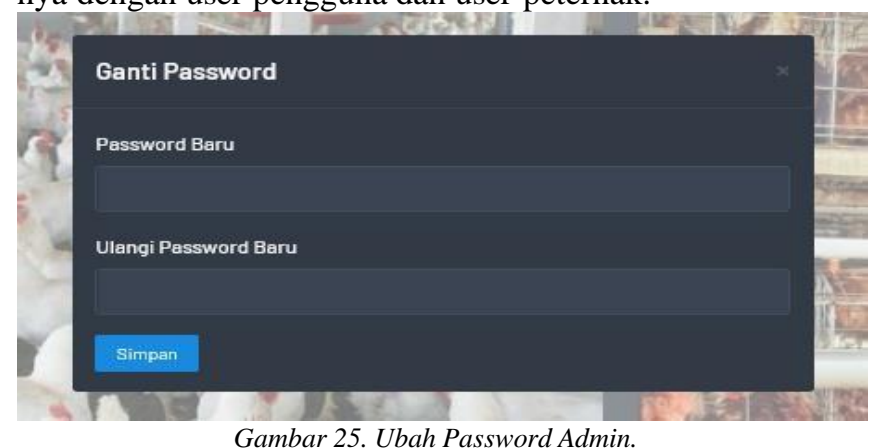

e-ISSN: 2685-7006 | p-ISSN: $2252-9063$

Kumpulan Artikel Mahasiswa Pendidikan Teknik Informatika

(KARMAPATI)

Volume 10, Nomor 2, Tahun 2021

\section{Halaman Utama Admin}

Halaman utama juga bisa diakses oleh admin, dan admin juga dapat melihat segala informasi yang ada pada halaman utama tersebut sama halnya seperti pengguna dan peternak.

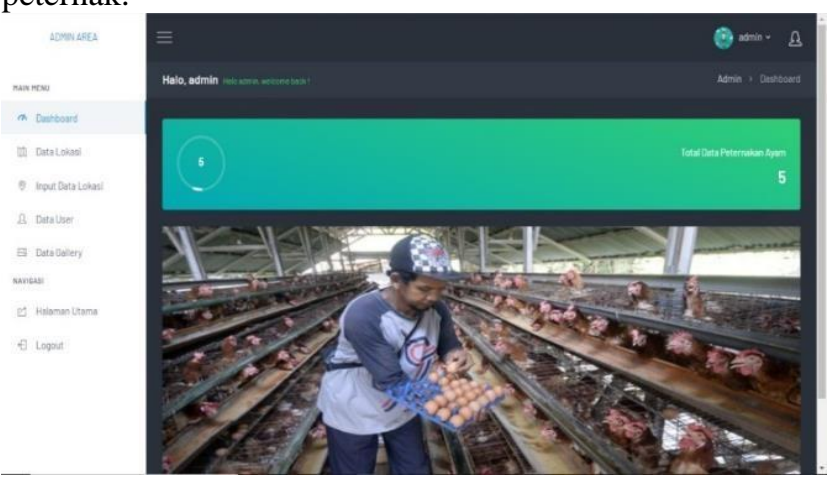

Gambar 26. Halaman Utama Admin

\section{Pengujian Sistem}

Berikut ini merupakan pengujian sistem dengan menggunakan metode blackbox testing, untuk mengetahui fungi dari setiap perangkat lunak yang ada, yang mana akan dilakukan rencana pengujian sebagai berikut :

Rencana Pengujian

Rencana Pengujian dilakukan untuk memetakan bagian-bagian dari sistem yang akan diuji. Berikut merupakan rencana pengujian sistem :

Tabel 1. Rencana Pengujian

\begin{tabular}{|c|c|c|c|c|c|}
\hline No & $\begin{array}{l}\text { Hasil yang } \\
\text { diuji }\end{array}$ & Action & $\begin{array}{l}\text { Hasilyang } \\
\text { diharapkan }\end{array}$ & $\begin{array}{l}\text { Hasil yang } \\
\text { didapat }\end{array}$ & Hasil \\
\hline \multicolumn{6}{|c|}{ Data Login } \\
\hline \multirow[t]{2}{*}{1} & \multirow[t]{2}{*}{$\begin{array}{l}\text { Login/ } \\
\text { Daftar }\end{array}$} & \multirow[t]{2}{*}{ Masuk } & $\begin{array}{l}\text { Berhasil } \\
\text { Login }\end{array}$ & $\begin{array}{l}\text { Berhasil Login } \\
\text { sistem }\end{array}$ & \multirow[t]{2}{*}{ Sesuai } \\
\hline & & & $\begin{array}{l}\text { Jika salah } \\
\text { gagal login }\end{array}$ & $\begin{array}{l}\text { Gagal login } \\
\text { sistem }\end{array}$ & \\
\hline \multicolumn{6}{|c|}{ Halaman Awal } \\
\hline 2 & $\begin{array}{l}\text { Halaman } \\
\text { Utama }\end{array}$ & Tampilan & $\begin{array}{l}\text { Halaman } \\
\text { utama } \\
\text { sistem GIS } \\
\text { Jembrana }\end{array}$ & $\begin{array}{l}\text { Berhasil } \\
\text { Menampilkan } \\
\text { Halaman } \\
\text { utama user }\end{array}$ & Sesuai \\
\hline \multicolumn{6}{|c|}{ Daftar Lokasi } \\
\hline 3 & $\begin{array}{l}\text { Daftar } \\
\text { Lokasi }\end{array}$ & Pemetaan & $\begin{array}{l}\text { Berhasil } \\
\text { mencari } \\
\text { lokasi } \\
\text { pemetaan }\end{array}$ & $\begin{array}{l}\text { Berhasil } \\
\text { mencari dan } \\
\text { mendapatkan } \\
\text { lokasi } \\
\text { pemetaan dari }\end{array}$ & Sesuai \\
\hline
\end{tabular}




\begin{tabular}{|c|c|c|c|c|c|}
\hline & & & & $\begin{array}{l}\text { setiap } \\
\text { perternak di } \\
\text { Kabupaten } \\
\text { Jembrana }\end{array}$ & \\
\hline \multicolumn{6}{|c|}{ Daftar User } \\
\hline 4 & Data User & $\begin{array}{l}\text { Profil } \\
\text { Pengguna }\end{array}$ & $\begin{array}{l}\text { Menampilka } \\
n \text { informasi } \\
\text { mengenai } \\
\text { profil } \\
\text { masing- } \\
\text { masing user } \\
\text { dan data } \\
\text { user }\end{array}$ & $\begin{array}{l}\text { Berhasil } \\
\text { menampilkan } \\
\text { informasi } \\
\text { mengenai } \\
\text { profil masing- } \\
\text { masing user } \\
\text { dan data user }\end{array}$ & Sesuai \\
\hline \multicolumn{6}{|c|}{ Data Gallery } \\
\hline 5 & Gallery & $\begin{array}{l}\text { Menampilka } \\
\text { n update } \\
\text { gallery dan } \\
\text { infromasi }\end{array}$ & $\begin{array}{l}\text { Melakukan } \\
\text { update } \\
\text { informasi } \\
\text { sistem } \\
\text { melalui } \\
\text { gambar dan } \\
\text { deskripsi }\end{array}$ & $\begin{array}{l}\text { Berhasil } \\
\text { melakukan } \\
\text { update } \\
\text { informasi } \\
\text { sistem melalui } \\
\text { gambar dan } \\
\text { deskripsi }\end{array}$ & Sesuai \\
\hline \multicolumn{6}{|c|}{ Detail Perternak } \\
\hline 6 & $\begin{array}{l}\text { Detail } \\
\text { Informasi } \\
\text { Peternak }\end{array}$ & $\begin{array}{l}\text { List } \\
\text { Peternakan }\end{array}$ & $\begin{array}{l}\text { Menampilka } \\
\mathrm{n} \text { infromasi } \\
\text { list peternak } \\
\text { dan detail } \\
\text { dari masing- } \\
\text { masing } \\
\text { peternak } \\
\text { tersebut }\end{array}$ & $\begin{array}{l}\text { Berhasil } \\
\text { menampilkan } \\
\text { infromasi list } \\
\text { perternak dan } \\
\text { detail dari } \\
\text { masing-masing } \\
\text { peternak } \\
\text { tersebut }\end{array}$ & Sesuai \\
\hline \multicolumn{6}{|c|}{ Log Out } \\
\hline 7 & Log Out & Keluar & $\begin{array}{l}\text { Keluar dari } \\
\text { sistem }\end{array}$ & $\begin{array}{l}\text { Berhasil keluar } \\
\text { sistem }\end{array}$ & Sesuai \\
\hline
\end{tabular}

\section{Hasil Wawancara}

Setelah pengujian berjalan sesuai dengan apa yang diharapkan oleh pengguna maka peneliti melakukan pengujian untuk mengetahui hasil dari penelitian tersebut sesuai dengan apa yang diharapkan oleh user pembeli dan peternak, maka peneliti melakukan wawancara mengenai sistem tersebut kepada 5 pembeli ayam diwilayah Kabupaten Jembrana, dan juga 5 peternak di Kabupaten Jembrana untuk mencoba menggunakan sistem yang telah penulis rancang, dari hasil wawancara dilakukan dengan metode blackboxtesting, jadi sistem diuji dengan mewawancara narasumber dengan menanyakan narasumberapakah sistem yang diuji berjalan sesuai dengan yang diharapkan oleh para narasumber yang menguji sistem tersebut (yaitu 5 pembeli ayam dan 5 perternak ayam Kabupaten Jembrana) dari wawancara pengujian yang dilakukan didapatkan hasil bahwa mereka semua senangdengan aplikasi tersebut dan menurut mereka aplikasi yang dirancang dapat membantu mereka dalam permasalahan yang selama ini mereka alami yaitu sulitnya menemukan lokasi peternakan ayam pada Kabupaten Jembrana terutamayang diam di pedalaman atau pelosok desa.

Tabel 2.Hasil Wawancara Dan Percobaan Penggunaan.

\begin{tabular}{|c|c|c|c|c|c|}
\hline $\mathrm{Na}$ & $\begin{array}{l}\text { Hasil yang } \\
\text { diuji }\end{array}$ & Action & $\begin{array}{l}\text { Hasil yang } \\
\text { diharapkan }\end{array}$ & $\begin{array}{l}\text { Hasil yang } \\
\text { didapat }\end{array}$ & Hasil \\
\hline \multicolumn{6}{|c|}{ Data Login } \\
\hline \multirow[t]{2}{*}{1} & \multirow[t]{2}{*}{$\begin{array}{l}\text { Login/ } \\
\text { Daftar }\end{array}$} & \multirow[t]{2}{*}{ Masuk } & $\begin{array}{l}\text { Berhasil } \\
\text { Login }\end{array}$ & $\begin{array}{l}\text { Berhasil Login } \\
\text { sistem }\end{array}$ & \multirow[t]{2}{*}{ Sesuai } \\
\hline & & & $\begin{array}{l}\text { Jika salah } \\
\text { gagal login }\end{array}$ & $\begin{array}{l}\text { Gagal login } \\
\text { sistem }\end{array}$ & \\
\hline \multicolumn{6}{|c|}{ Halaman Awal } \\
\hline 2 & $\begin{array}{l}\text { Halaman } \\
\text { Utama }\end{array}$ & Tampilan & $\begin{array}{l}\text { Halaman } \\
\text { utama } \\
\text { sistem GIS } \\
\text { Jembrana }\end{array}$ & $\begin{array}{l}\text { Berhasil } \\
\text { Menampilkan } \\
\text { Halaman } \\
\text { utama user }\end{array}$ & Sesuai \\
\hline \multicolumn{6}{|c|}{ Daftar Lokasi } \\
\hline 3 & \begin{tabular}{|l|} 
Daftar \\
Lokasi
\end{tabular} & Pemetaan & $\begin{array}{l}\text { Berhasil } \\
\text { mencari } \\
\text { lokasi } \\
\text { pemetaan }\end{array}$ & $\begin{array}{l}\text { Berhasil } \\
\text { mencari dan } \\
\text { mendapatkan } \\
\text { lokasi } \\
\text { pemetaan dari } \\
\text { setiap } \\
\text { perternak di } \\
\text { Kabupaten } \\
\text { Jembrana }\end{array}$ & Sesuai \\
\hline \multicolumn{6}{|c|}{ Daftar User } \\
\hline 4 & Data User & $\begin{array}{l}\text { Profil } \\
\text { Pengguna }\end{array}$ & $\begin{array}{l}\text { Menampilka } \\
n \text { informasi } \\
\text { mengenai } \\
\text { profil } \\
\text { masing- } \\
\text { masing user } \\
\text { dan data } \\
\text { user }\end{array}$ & $\begin{array}{l}\text { Berhasil } \\
\text { menampilkan } \\
\text { informasi } \\
\text { mengenai } \\
\text { profil masing- } \\
\text { masing user } \\
\text { dan data user }\end{array}$ & Sesuai \\
\hline \multicolumn{6}{|c|}{ Data Gallery } \\
\hline 5 & Gallery & $\begin{array}{l}\text { Menampilka } \\
n \text { update } \\
\text { gallery dan } \\
\text { infromasi }\end{array}$ & $\begin{array}{l}\text { Melakukan } \\
\text { update } \\
\text { informasi } \\
\text { sistem } \\
\text { melalui } \\
\text { gambar dan } \\
\text { deskripsi } \\
\end{array}$ & $\begin{array}{l}\text { Berhasil } \\
\text { melakukan } \\
\text { update } \\
\text { informasi } \\
\text { sistem melalui } \\
\text { gambar dan } \\
\text { deskripsi }\end{array}$ & Sesuai \\
\hline \multicolumn{6}{|c|}{ Detail Perternak } \\
\hline 6 & $\begin{array}{l}\text { Detail } \\
\text { Informasi } \\
\text { Perternak }\end{array}$ & $\begin{array}{l}\text { List } \\
\text { Peternakan }\end{array}$ & $\begin{array}{l}\text { Menampilka } \\
n \text { infromasi } \\
\text { list peternak } \\
\text { dan detail } \\
\text { dari masing. } \\
\text { masing } \\
\text { perternak } \\
\text { tersebut }\end{array}$ & $\begin{array}{l}\text { Berhasil } \\
\text { menampilkan } \\
\text { infromasi list } \\
\text { peternak dan } \\
\text { detail dari } \\
\text { masing-masing } \\
\text { perternak } \\
\text { tersebut }\end{array}$ & Sesuai \\
\hline \multicolumn{6}{|c|}{ Log Out } \\
\hline 7 & Log Out & Keluar & $\begin{array}{l}\text { Keluar dari } \\
\text { sistem }\end{array}$ & $\begin{array}{l}\text { Berhasil keluar } \\
\text { sistem }\end{array}$ & Sesuai \\
\hline
\end{tabular}

Tabel diatas adalah tabel hasil pengujian penggunaan 5 pembeli ayam dan 5 perternak ayam Kabupaten Jembrana, dan ada beberapa pertanyaan yang dilampirkan untuk memperkuat hasil dari penelitian tersebut yang dilampirkan pada halaman lampiran, maka dari hasilimplementasi dan pengujian yang dilakukan diperoleh bahwa sistem GIS yang dibuat sudah berjalan sesuai denganapa yang diharapkan.

Selain itu peneliti juga melakukan penyebaran kuesioner kepada 20 orang responden yang dicampur dari responden peternak dan juga responden pembeli ayam dengan metode System Usability Scale (SUS) dengan hasil sebagai berikut : 


\section{e-ISSN: 2685-7006 | p-ISSN: 2252-9063 \\ Kumpulan Artikel Mahasiswa Pendidikan Teknik Informatika \\ (KARMAPATI) \\ Volume 10, Nomor 2, Tahun 2021}

KคRMดPคTI

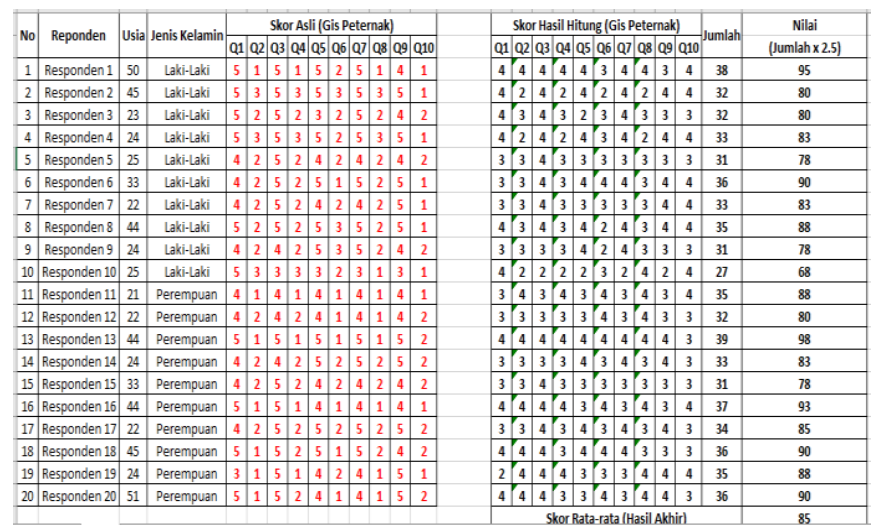

Gambar 27. Hasil Kuesioner SUS Gis Peternak.

Dari hasil tersebut dapat disimpulkan dari 20 responden $85 \%$ mengatakan bahwa sistem yang telah dirancang mudah digunakan,akan digunakan, berjalan sebagaimana mestinya mudah dipahami dan tidak memiliki hambatan terhadap sistem GIS perternakan tersebut, hal tersebut dibuktikan dari hasil kuesioner yang didapat dari 20 responden yang dibagi menjadi 2 golongan yaitu golongan pertama dari pihak peternakan dan golongan kedua dari pihak pembeli ayam, pertanyaan yang ditanyakan sudah menyesuaikan prosedur dari metode kuesioner SUS dan setiap pertanyaan dan jawaban dilampirkan pada halaman lampiran, dan semua jawaban tersebut sudah diolah kedalam perhitungan kuesioner SUS sehingga diperoleh $85 \%$ setuju dengan adanya sistem ini akan membantu mereka dalam permasalahan yang dihadapi sebelumnya, baik dari pihak peternak maupun pembeli ayam.

\section{SIMPULAN}

Berdasarkan hasil penelitian ini maka dapat disimpulkan bahwa setelah melakukan pembangunan aplikasi berbasis website dengan menggunakan bahasa pemograman PHP dengan bantuan framework CodeIgniter dan mysql sebagai databasenya didapatkan hasil bahwa sistem yang telah dirancang telah berjalan sesuai dengan apa yang diharapkan tanpa adanya bug maupun error pada aplikasi tersebut dan juga mampu memberikan output sesuai dengan apa yang diharapkan, sistem dapat memberikan informasi pemetaan untuk para pembeli ayam sehingga memudahkan mereka dalam mengetahui lokasi dari masing- masing perternakan ayam pada Kabupaten Jembrana Bali, selain itu perternak juga terbantu dengan adanya sistem tersebut sehingga menjadi lebih dikenal dan mudah dikunjungi oleh pembeli, Setelah dilakukan implementasi sistem dengan pengujian black box testing aplikasi yang dirancang sudah sesuai dengan apa yang diharapkan oleh user sehingga layak untuk dipublikasikan ke user pengguna/pembeli serta perternak di Kabupaten Jembrana Bali, dari hasil implementasi yang dilakukan dengan mewawancarai 5 orang pembeli dan 5 perternak didapatkan hasil bahwa sistem yang dirancang telah sesuai dengan yang dibutuhkan oleh pengguna dan peternak tersebut, data tersebut juga didukung oleh hasil penyebaran kuesioner kepada 20 responden yang menghasilkan persentase $85 \%$ sistem GIS Perternakan diagap mudah untuk digunakan dan sesuai dengan harapan mereka serta membantu permasalahan dinas perternakan, peternak ayam serta pembeli ayam di Kabupaten Jembrana Bali dalam menerima informasi tataletak peternakan ayam di Jembrana Bali.

Berdasarkan hasil penelitian yang diperoleh maka dapat diajukan beberapa saran yaitu (1) Sistem diharapkan kedepannya dapat dikembangkan dan diimplementasikan kedalam mobile apps berbasis android ataupun ios., (2)Sistem kedepannya diharapkan terus berkembang agar dapat bermanfaat bagi banyak orang.

\section{REFERENCES}

[1] T.Pemkap, "Kabupaten Jembrana," vol. 1(5), 2014.

[2] K. M. Wibowo, "Sistem Informasi Geografis (Sig) Menentukan Lokasi Pertambangan Batu Bara Di Provinsi Bengkulu Berbasis Website," Bengkulu J. Media Infotama, 2015.

[3] E. Priyatna and Dkk, "Analisis strategi pengembangan usaha peternakan ayam pedaging (boiler) ananta guna di Desa Sidan Kecamatan Gianyar Kabupaten Gianyar.," Singaraja J. JPPE, 2016.

[4] Harahap and Iksal, "Aplikasi Sistem Informasi Geografis (Sig) Untuk Zonasi Jalur Penangkapan Ikan Di Perairan Kalimantan Barat," Bandung J. Akuatika, 2012.

[5] M. R. Arief, Pemrograman Web Dinamis Menggunakan PHP dan MYSQL. Yogyakarta: Andi, 2011.

[6] B. Restu, "Perancangan Prototype Sistem Informasi Pergudangan Dengan Menggunakan Teknologi Radio Frequency Identification(RFId)DI PT. SRIWAHANA ADITYAKARTA BOYOLALI," Universitas 11 Maret, 2011. 